\title{
Effects of dual land ownerships and different land lease terms on industrial land use efficiency in Wuxi City, East China
}

Article

Accepted Version

Creative Commons: Attribution-Noncommercial-No Derivative Works 4.0

Ye, L., Huang, X., Yang, H., Chen, Z., Zhong, T. and Xie, Z. (2018) Effects of dual land ownerships and different land lease terms on industrial land use efficiency in Wuxi City, East China. Habitat International, 78. pp. 21-28. ISSN 0197-3975 doi: https://doi.org/10.1016/j.habitatint.2018.04.011 Available at https://centaur.reading.ac.uk/80027/

It is advisable to refer to the publisher's version if you intend to cite from the work. See Guidance on citing.

To link to this article DOI: http://dx.doi.org/10.1016/j.habitatint.2018.04.011

Publisher: Elsevier

All outputs in CentAUR are protected by Intellectual Property Rights law, including copyright law. Copyright and IPR is retained by the creators or other copyright holders. Terms and conditions for use of this material are defined in the End User Agreement. 


\section{CentAUR}

Central Archive at the University of Reading

Reading's research outputs online 


\title{
Effects of dual land ownerships and different land lease terms on industrial land use efficiency in Wuxi City, East China
}

\author{
Lifang Ye ${ }^{\mathrm{a}}$, Xianjin Huang ${ }^{\mathrm{a}, \mathrm{b}, *}$, Hong Yang ${ }^{\mathrm{a}, \mathrm{c}, * *}$, Zhigang Chen $^{\mathrm{a}}$, Taiyang Zhong ${ }^{\mathrm{a}}$, Zelin Xie $^{\mathrm{a}}$ \\ ${ }^{\text {a }}$ School of Geography and Ocean Science, Nanjing University, 163 Xianlin Avenue, Nanjing, China \\ b The Key Laboratory of the Coastal Zone Exploitation and Protection, Ministry of Land and Resources, \\ Nanjing, China \\ ${ }^{\mathrm{c}}$ Department of Geography and Environmental Science, University of Reading, Reading, RG1 6AB, UK
}

* Corresponding author. School of Geography and Ocean Science, Nanjing University, 163 Xianlin Avenue, Nanjing, China.

** Corresponding author. Department of Geography and Environmental Science, University of Reading, Reading, RG1 6AB, UK.

E-mail addresses: sunny.juliana@126.com (L. Ye), hxj369@nju.edu.cn (X. Huang), hongyanghy@gmail.com (H. Yang), zgchen@nju.edu.cn (Z. Chen), taiyangzhong@163.com (T. Zhong), 41892158@qq.com (Z.Xie).

\begin{abstract}
In the current Chinese land administration system, two types of land ownership including state and collective ownership coexist and the industrial land use rights can be transferred between different land lease terms. Previous studies found the significant relationship between land ownerships and lease terms with agriculture land use efficiency, but it is still unclear for the industrial land use efficiency. This study researched the effects of China's dual land ownerships and land lease terms on rural town industrial land use efficiency. Questionnaires of 294 industrial enterprises in Hudai, Qianqiao, and Xibei in Wuxi City, East China, were studied using two multiple linear regression models. The results showed that collective land with incomplete property rights caused land use inefficiency of lower industrial enterprises' output per hectare of land. The industrial enterprises' outputs per hectare from collective land were 2.16 million Yuan ( 0.31 million US dollar) and 2.06 million Yuan (0.30 million US dollar) less than those from state land in these two models, respectively. Different land lease terms negatively correlated with the use efficiency of rural industrial land. The outputs per hectare of industrial enterprises using the long term lease were 1.30 million Yuan (0.19 million US dollar) less than those using the short term lease in model 2. Our results highlight the importance of the integrated urban-rural land system and tailored lease terms of industrial land to increase the utilization efficiency of industrial land.
\end{abstract}

Key words: land ownership; land lease term; transaction type; land use efficiency; urban-rural land system; China. 


\section{Introduction}

High use efficiency of land resources can relieve the conflict between increasing population and limited land (Kuang et al., 2016, Tang and Ho, 2015, Wu et al., 2014). With rapid urbanization and industrialization in China, the human-land relationship has been more and more intense. The low efficiency of industrial land use has received increasing attention from the government and public (Du et al., 2016). Almost all levels of government in China have made relevant policies and regulations to improve the efficiency of industrial land use (Choy et al., 2013). Rural land use has also received increasing attention (Long et al., 2009, Liu et al., 2014).

\subsection{Institutional background in China}

China's urbanization and industrialization process is different from most countries, which is based on a unique institution called the urban-rural dual land system (Chen et al., 2007, Choy et al., 2013, Ding, 2007, Koroso et al., 2013). China's constitution decrees that rural land is owned by the "collectives" and urban land is owned by the "state". According to the relevant provisions of the Land Management Law of People Republic of China, the market exchange of the collective construction land is forbidden in rural areas (Chen et al., 2015b). Any rural land to be transferred to the private sector must be firstly expropriated by the state (Lin, 2010). In the process, the private sector must pay a comprehensive conveyance fee to the state, compensation fees to the collective, and other administrative fees (Bao and Peng, 2016). It is illegal to directly use collective land for non-agricultural purpose (Tian and Zhu, 2013, Wang et al., 2017, Zhang, 2013). In order to prevent land to be expropriated and also for economic development, village collective or farmers sometimes sell agricultural land directly to the enterprises and individuals without legal expropriation in some areas (Hao et al., 2011, Po, 2008, Tian, 2008, Zhong et al., 2014). Although farmers do not have the legal right to change the use of rural collective land, farmers make the effort to protect their land ownership by illegally converting the collective land (Liu et al., 2012, Xu et al., 2011). For example, they usually transferred land use rights of rural collective by means of land-renting instead of expropriating and grabbing land and illegally building, expanding or renovating houses (Chen et al., 2015a).

In China's current urban and rural land system, there are two land ownerships including the state-owned land ownership and collective land ownership, but they are unequal. According to the Provisional Regulations of Urban State-Owned Land Use Right Transfer in China in 1990, stateowned lands can be sold, transferred and mortgaged, but the collective lands cannot. The collective land is at the risk of being expropriated by local communities (Choy et al., 2013). There is concern that whether two different land ownerships will cause differences of land use efficiency.

At present, the maximum lease term of China's industrial land is 50 years. According to the State Administration for Industry and Commerce in 2008-2012, 59.1\% Chinese enterprises can survive in less than 5 years, $24.9 \%$ can survive in 6-9 years, $12.8 \%$ can survive in $10-19$ years, and only $3.2 \%$ can survive for over 20 years. Comparison of the life cycle of most enterprises, the use term of industrial land is very long in China, with the consequence of idle use of industrial land. Therefore, the Chinese government is considering to shorten the lease term of industrial land and to adopt a flexible grant period. However, it is also concerned that the shortened lease term may reduce 
the use efficiency of industrial land.

\subsection{Theoretical background and literature review}

Property right is the exclusive authority to determine how a resource is used, and its arrangement has marked effects on the resource use efficiency (Coase, 1960). The secured land rights can increase investment and promote efficient allocation of land resource (Besley, 1995, Deininger and Jin, 2006, Field, 2007, Galiani and Schargrodsky, 2010, Jin and Deininger, 2009). In other word, different ownership arrangements may lead to variable land use efficiency (Barry and Roux, 2016).

There are studies on the influence of land property rights on the land use efficiency in the agricultural sector (Galiani and Schargrodsky, 2010, Koirala et al., 2016, Ma et al., 2015, Manjunatha et al., 2013). From the theoretical perspective, the most obvious effect of land property right insecurity is the uncertainty of obtaining benefits from the farmers' investment on the farmland (Deininger and Ali, 2008, Feder and Onchan, 1987, Ma et al., 2015). Therefore, clear property right is the key to promote long-term investment and effective utilization of land. On the contrary, the ambiguous property right is the root cause of many land issues: inefficient and wasteful land use, excessive conversion and development, and competition and disputes over land access (Lin, 2010, Wang et al., 2015). Similarly, the unclear collective land ownership in China limit the effective incentives to promote effective utilization of land (Putterman, 1995).

Previous studies have provided useful information to understand the rural town industrial land use in the rapid process of urbanization (Choy et al., 2013, Kuang et al., 2016, Meng et al., 2008, Tu et al., 2014). The studies on the effect of land property rights on land use efficiency are mainly about the agricultural land (Awasthi, 2009, Rahman, 2010). However, the studies on the influence of land ownerships on the industrial land use efficiency are still rare. It is still unclear about the effect of China's two land ownerships on the use efficiency of rural town industrial land.

Long-term land lease can reduce transaction costs (Feder and Onchan, 1987, Kumari and Nakano, 2016, Gavian and Fafchamps, 1996, Gavian and Ehui, 1999), while short-term lease will reduce the entrepreneur's willingness to expand investment. Studies found that short-term agricultural land lease could reduce the expected returns of long-term investment, causing inefficiency of land use (Abdulai et al., 2011, Koirala et al., 2016, Manjunatha et al., 2013, Rahman and Rahman, 2009). However, it is still not very clear about the effect of different industrial land lease terms on the efficiency of industrial land use.

\subsection{Theoretical hypotheses}

Previous studies suggested clear property right was the key to promote effective utilization of land (Deininger and Ali, 2008, Feder and Onchan, 1987, Ma et al., 2015). The state-owned industrial land ownership is protected by law. The collective industrial land ownership from informal market is not protected by law, so there is the risk of the land requisition by the state. It is generally accepted that state-owned land ownership is securer than the collective land ownership. Therefore, our first hypothesis is as follows: the use efficiency of state-owned industrial land is higher than that of collective industrial land. 
The effect of land lease terms on land use efficiency has received attention in China and other countries (Koirala et al., 2016, Kumari and Nakano, 2016, Pender and Fafchamps, 2006). In terms of agricultural land, the longer the land lease term is, the more the land users invest, and the higher the land use efficiency is (Kumari and Nakano, 2016). We investigate if there is a similar law for industrial land and proposed the second hypothesis: the longer land lease term will cause more investment and higher efficiency of industrial land.

To the best of our knowledge, there is no study on industrial land use efficiency integrating urban and rural land market. Because the collective land market is an invisible informal market and the transaction data are generally unavailable, most previous studies are qualitative analyses (Wang and $\mathrm{Hu}, 2011$, Zhang, 2014, Zhang and Chen, 2008).In this study, we made the first attempt to evaluate the effect of different land ownerships and lease terms on the efficiency of rural town industrial land based on our questionnaire survey data in East China. Wuxi City was selected as study area as it is at the forefront of China's land market reform and is a typical area where stateowned industrial land and collective industrial land coexist. In Wuxi, the industrial enterprises acquire state-owned or collective land to set up plants in different transaction types with long-term lease (30-50 years) or short-term lease (1-5 years).

The text is divided into six parts, the second part is Institutional background in Wuxi, the third part is Model and data, the fourth part is Results, the fifth part is Discussion, and the sixth part is Conclusion.

\section{Institutional background in Wuxi}

\subsection{Wuxi's construction land market development}

There has been a unique rural construction land market in Wuxi City. By interviewing with staff in land management department in Wuxi City and village cadres in three towns, the following was researched: the development process of Wuxi construction land market, transfer policy of collective construction land, and the land double replacement policy. Development of construction land market in Wuxi went through four stages.

(1) The exploration stage (1995-2000)

During the period of 1995-2000, the reform of the property right system was carried out in many township enterprises. How to dispose of the stock of the collective construction land was the main challenge for the land management department. Village collective enterprise assets were leased or sell to individuals, and the individuals gained the collective industrial land by collective land onetime buyout or annual collective land rent in this period. Industrial land was mainly original township land. The annual collective land rent was 75-90 thousand Yuan/hectare/year (10.85-13.01 thousand US dollars /hectare/year), and collective land one-time buyout price was 750-900 thousand Yuan/ hectare (108.45-130.14 thousand US dollars /hectare).

(2) The fast development stage (2001-2004)

During the period of 2001-2004, collective land transfer developed rapidly. Economic zones began to be developed in 2001, resulting in a large amount of high quality cultivated land was converted to industrial land. To promote the relocation of enterprises, a large amount of new industrial land was transferred by state-owned land transfer or collective land one-time buyout. 
(3) The standardization stage (2005-2009)

In the period of 2005-2008, newly increased construction land was mainly transferred by stateowned land transfer or annual collective land rent, but it was rarely transferred by collective land one-time buyout after 2005. In 2008, Wuxi government released the "Interim measures to manage collective construction land use rights transfer in Wuxi City", governing transfer of the collective construction land.

(4) The stable stage (2010-2016)

During the period of 2010-2016, the new industrial land was mainly obtained by expropriating farmland land into state-owned land and the newly increased collective construction land was rare. Remote sensing technique was employed for prospecting farmland and detecting farmland conversion. Wuxi had carried out the land double replacement policy which means that "Farmland contracting right exchanges for urban social security, and rural housing exchanges for urban housing". The land double replacement policy has led to newly increased state-owned industrial land.

\subsection{Industrial land transaction in Wuxi}

According to our survey, there are three main industrial land transaction types in Wuxi City: state-owned land transfer, collective land one-time buyout, and annual collective land rent (Table $1)$.

State-owned land transfer means that the state transfers the state-owned land right to the land users within a certain period of time, and the land users need pay land-transferring fees to the state (Gao et al., 2014). The subject of circulation is often the government, and the land lease term is often 30-50 years. State-owned land ownership is clear and protected by law. The land property rights contain land-use right, mortgage right, transfer right and so on. According to our survey, the land lease price was 5250-7500 thousand Yuan/ hectare (759.15-1084.50 thousand US dollars /hectare) in 2015.

Collective land one-time buyout means that the collective transfers the collective land right to the land users within a certain period of time, and the land users need pay land-transferring fees to the collective. Similar as the state-owned land transfer, the land lease term is often 30-50 years, but the subject of circulation is the village collective, rather than the government. The land ownership is not protected by law. It contains only land-use right. According to our survey, the land lease price was cheaper than the state-owned land, only 750-1500 thousand Yuan/hectare (108.45-216.90 thousand US dollars /hectare) in 2015.

Annual collective land rent means the village collective transfers the collective land right to the land users in terms of annual rent, and the land users need pay annual rent to the collective. The subject of circulation is often the village collective, and the land lease term is usually 1-5 years. The land ownership is not protected by law. It contains only land-use right. According to our survey, the land lease price was 150-195 thousand Yuan/hectare/year (21.69-28.20 thousand US dollars /hectare/year) in 2015. 
Table1. Different land transaction types in Wuxi City

\begin{tabular}{|c|c|c|c|c|c|}
\hline $\begin{array}{c}\text { Transaction } \\
\text { types }\end{array}$ & Land sources & Lease term & $\begin{array}{c}\text { Content of land property } \\
\text { rights }\end{array}$ & $\begin{array}{l}\text { Property } \\
\text { legitimacy }\end{array}$ & Price level \\
\hline $\begin{array}{l}\text { State-owned } \\
\text { land transfer }\end{array}$ & Government & 30-50years & $\begin{array}{l}\text { Land-use right, mortgage } \\
\text { right, transfer right and so } \\
\text { on }\end{array}$ & Legal & $\begin{array}{l}\text { 5250-7500 thousand Yuan/ } \\
\text { hectare (759.15-1084.50 } \\
\text { thousand US dollars /hectare) }\end{array}$ \\
\hline $\begin{array}{l}\text { Collective land } \\
\text { one-time buyout }\end{array}$ & $\begin{array}{l}\text { Village } \\
\text { collectives }\end{array}$ & $30-50$ years & Land-use right & Illegal & $\begin{array}{c}\text { 750-1500 thousand Yuan/hectare } \\
\text { (108.45-216.90 thousand US } \\
\text { dollars /hectare) }\end{array}$ \\
\hline $\begin{array}{l}\text { Annual } \\
\text { collective land } \\
\text { rent }\end{array}$ & $\begin{array}{l}\text { Village } \\
\text { collectives }\end{array}$ & $1-5$ years & Land-use right & Illegal & $\begin{array}{c}\text { 150-195 thousand } \\
\text { Yuan/hectare/year (21.69-28.20 } \\
\text { thousand US dollars } \\
\text { /hectare/year) }\end{array}$ \\
\hline
\end{tabular}

\section{Model and data}

\subsection{Model setting}

Similar as previous researches (Chen et al., 2014, Chen et al., 2016, Meng et al., 2008, Tu et al., 2014, Wu et al., 2017, Xie and Wang, 2015, Xiong and Guo, 2013), capital output intensity of land was selected as an indicator to reflect the industrial land use efficiency. The industrial output divided by land area was calculated to reflect capital output intensity of industry land.

The multiple linear regression model has been used in the previous studies (Choy et al., 2013, Fenske, 2011, Liu et al., 2010, Tao et al., 2010), and we used two similar models to examine the effects of dual land ownerships and different land lease terms on industrial land use efficiency. In the models, the dependent variable was the industrial output divided by land area, which indicated capital output intensity of industry land. In order to verify our theoretical hypothesis, land ownership and land use term were selected as explanatory variables into the models.

In addition, land output is affected by land, capital and labor input (Trischler et al., 2014, Wu et al., 2017), so LandArea, DJinvestment, DJemployee were selected as the explanatory variables into the model 1. Model 1 was shown in Eq. (1).

$$
\text { DJoutput }=C+a_{1} \text { Ownership }+a_{2} \text { Tranction }+a_{3} \text { LandArea }+a_{4} \text { DJinvest }+
$$
$a_{5}$ DJemployee $+\varepsilon . \quad(1)$

As some research mentioned that property rights and land lease terms may affect the investment decisions of land, capital and labor (Abdulai et al., 2011, Deininger et al., 2011, Brasselle et al., 2002), in order to test the endogeneity issue, model 2 was built without the three variables (LandArea, DJinvestment, DJemployee). Model 2 was shown in Equation (2).

$$
\text { DJoutput }=C+a_{1} \text { Ownership }+a_{2} \text { Tranction }+\varepsilon \text {. }
$$

In Eqs. (1) and (2), DJoutput is industrial land use efficiency across the related studies (DJoutput equals to the output of the enterprise divided by the land area of the enterprise (Chen et 
al., 2014, Chen et al., 2016, Xie and Wang, 2015)); Ownership is dummy variable, reflecting the property right differences of industrial land (state-owned land has been assigned the value 1 , while collective land has been assigned the value 0); Tranction is dummy variable, reflecting industrial land lease term selection (long-term lease (30-50years) has been assigned the value 1, while shortterm lease (1-5years) has been assigned the value 0); LandArea is the land area of the enterprise; DJinvestment is the intensity of capital investment of the villages and towns industrial land (DJinvestment equals to the investment of the enterprise divided by the land area of the enterprise); DJemployee is the intensity of labor force input of the villages and towns industrial land (DJemployee equals to the employees of the enterprise divided by the land area of the enterprise); $a_{1}, a_{2}, a_{3}, a_{4}, a_{5}$ are the corresponding variable coefficients; $C$ and $\varepsilon$ are constant term and random disturbance of the model. Description of these variables selected in the models is available in Table 2.

Table2. Units, definitions and expected signs of variables

\begin{tabular}{|c|c|c|c|}
\hline Variables & Units & Definitions & $\begin{array}{l}\text { Expected } \\
\text { signs }\end{array}$ \\
\hline DJoutput & $\begin{array}{l}\text { Thousand US } \\
\text { dollars/ hectare }\end{array}$ & $\begin{array}{l}\text { Reflects rural town industrial land use } \\
\text { efficiency. Output divided by Land area }\end{array}$ & l \\
\hline Ownership & Dummy variable & $\begin{array}{c}\text { Property right types (1for state-owned land, } 0 \\
\text { for collective land) }\end{array}$ & + \\
\hline Transaction & Dummy variable & $\begin{array}{l}\text { Land lease terms ( } 1 \text { for long-term lease (30- } \\
50 \text { years) ,0 for short-term lease (1-5years)) }\end{array}$ & + \\
\hline LandArea & Hectare & The land area of the enterprise & l \\
\hline DJinvestment & $\begin{array}{l}\text { Thousand US } \\
\text { dollars/ hectare }\end{array}$ & $\begin{array}{l}\text { Investment divided by Land area (the theory } \\
\text { of input and output) }\end{array}$ & + \\
\hline DJemployee & Number / hectare & $\begin{array}{l}\text { Employees divided by Land area (the theory } \\
\text { of input and output) }\end{array}$ & + \\
\hline
\end{tabular}

\subsection{Study area}

The current study was conducted in Wuxi City $\left(119^{\circ} 31^{\prime} \sim 120^{\circ} 36^{\prime} \mathrm{N}, 31^{\circ} 07^{\prime} \sim 32^{\circ} 00^{\prime} \mathrm{E}\right)$, the southeast of Jiangsu Province, East China (Fig. 1). The total area of Wuxi is $4626 \mathrm{~km}^{2}$, and $25.47 \%$ and $26.30 \%$ of the area are cultivated land and industrial land. Wuxi is one of central cities in the Yangtze River Delta, the birthplace of China's township enterprises (Zhang, 2005). In 2014, Wuxi's total GDP was 820.53 billion Yuan (118.65 billion US dollars) and per capita GDP was 126389 Yuan (18276 US dollars). The value-added of secondary industry was 418.63 billion Yuan (60.53 billion US dollars) and the GDP ratio between three industries was 1.9:51.0:47.1. The total population of permanent residents was 6.50 million and the urbanization rate was $74.47 \%$. The ratio of per capita of disposable income between city dwellers and rural residents was $1.87: 1$, and the ratio of per capita living expenditures for consumption between urban and rural residents was 1.81:1 
(Statistics, 2015).

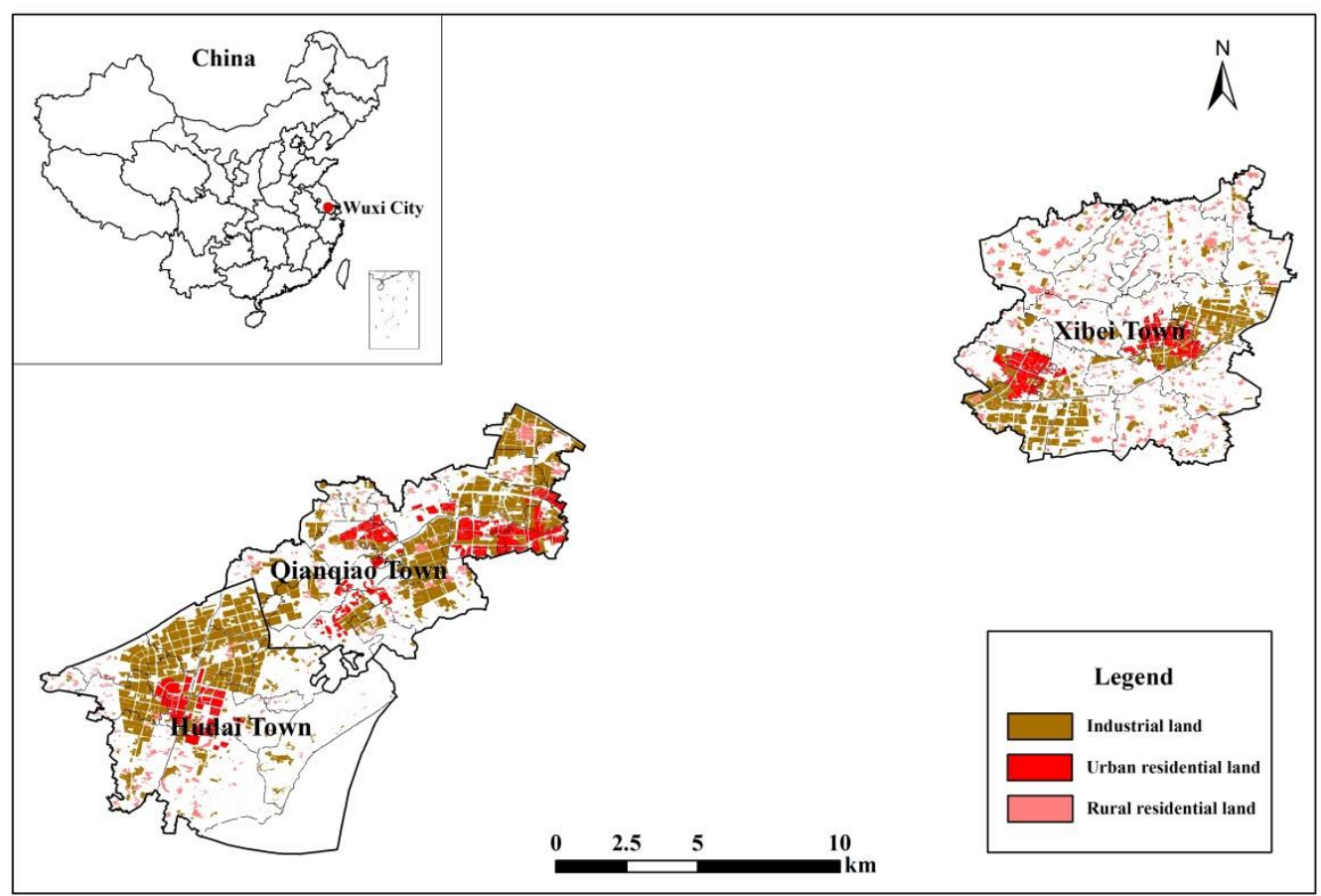

Fig.1 Distribution of construction land in Hudai Town, Qianqiao Town and Xibei Town in Wuxi City, East China

Wuxi City explored the collective construction land circulation policy and introduced market methods to deal with the collective land resource in township enterprises in the early 1990s (Shiraishi and Yano, 2010, Yano and Shiraishi, 2004). Wuxi started trial annual land rent system in 1998 and set up land double replacement policy in 2009. Land demand from different industries is an intense competition and there are many problems including unreasonable land use structure, inefficiency of land using, high proportions of industrial land, farmland conversion, and others. With the increasing industrialization and urbanization, the situation is becoming worse.

Hudai Town, Qianqiao Town and Xibei Town are relatively developed areas in Wuxi City (Ye et al., 2015). Proportions of industrial land in Hudai, Qianqiao and Xibei reached 56.25\%, 41.30\%, $65.03 \%$, respectively in 2014. State-owned industrial land and collective industrial land coexist. The collective land accounted for $33.95 \%, 42.19 \%, 33.80 \%$, respectively, of total industrial land area in the three towns, and the rest were state-owned land (Ye et al., 2015). The enterprises using the collective industrial land are mainly small and medium-sized enterprises, and land areas of these enterprises are usually less than those of the enterprises using the state-owned industrial land. Small businesses start earlier and the distribution is wide. They are very representative of the rural township industry development in Wuxi, and therefore these three towns were selected as study area in the current study.

The industrial land is concentrated in the north of Hudai Town, while it dispersed widely in Qianqiao Town and Xibei Town (Fig.1). The industrial land usually expands along the major roads, 
while the rural town industrial land is interweaved with the rural residential land.

\subsection{Data sources}

The social and economic data used in this research were obtained from 2015 Wuxi Statistical Yearbook, and the land use data were obtained from the Land Resources Bureau in Wuxi. All the required data for the model run were obtained from questionnaire survey.

We surveyed 40 villages in the 3 towns. Total of 351 enterprises were surveyed using questionnaire, and the valid sampling rate was $83.76 \%$. Enterprises were selected according to the following principle: Approximately 3-5 enterprises were randomly selected in the villages with no more than 30 enterprises. Approximately 10-15 enterprises were randomly selected in villages with more than 30 enterprises. Table 3 shows the distribution of the samples.

Table3. The distribution of the samples

\begin{tabular}{|c|c|c|c|c|}
\hline $\begin{array}{c}\text { Township } \\
\text { name }\end{array}$ & $\begin{array}{c}\text { District } \\
\text { name }\end{array}$ & Village name & $\begin{array}{c}\text { Number } \\
\text { of } \\
\text { villages }\end{array}$ & $\begin{array}{c}\text { Number } \\
\text { of } \\
\text { Samples }\end{array}$ \\
\hline Hudai & Binhu & $\begin{array}{c}\text { Fuan , Hongxiang, Hudai, Liyuan } \\
\text { development zone, Liutang, Longyan, } \\
\text { Mengcun, Xifeng, Xiadu, Zhangshe, } \\
\text { Maan }\end{array}$ & 11 & 122 \\
\hline Qianqiao & Huishan & $\begin{array}{l}\text { Dongfeng, Huaxin , Nantang, Nanxi, } \\
\text { Ouleyuaan ,Qianhu, Shaotang, } \\
\text { Shengfeng, Shuanke, Sumiao , } \\
\text { Xizhang, Xinan, Xiaofeng, Xiaoxing, } \\
\text { Yangxi , Qianqiao industrial park }\end{array}$ & 15 & 128 \\
\hline Xibei & Xishan & $\begin{array}{l}\text { Bashi, Chunfeng, Dongfeng, Doushan, } \\
\text { Guangming, Jingfeng , Jingxi , Jingxin, } \\
\text { Lianxin, Xibei industrial park, Xinba, } \\
\text { Zhaimen, Zhangjing, Zhoujiage }\end{array}$ & 14 & 101 \\
\hline
\end{tabular}

\section{Results}

Samples were grouped according to different land ownerships and land lease terms. By comparing means of different group sample, the enterprises using the state-owned land had more land than those using the collective land (Table 4). Enterprises with long-term lease also had more land than those with short-term lease. The investment and annual outputs per hectare in the stateowned land samples (3403.37 Yuan (492.13 US dollars) per hectare; 5747.07 Yuan (831.03 US dollars) per hectare) were higher than those in the collective land samples (2354.97Yuan (340.53 US dollars) per hectare; 4627.85Yuan (669.19 US dollars) per hectare). The investments per hectare in the long-term lease samples (2935.67Yuan (424.50 US dollars) per hectare) were greater than those in the short-term lease samples (2221.01Yuan (321.16 US dollars) per hectare), while the 
annual outputs per hectare in the long-term lease samples (4351.85Yuan (629.28US dollars) per hectare) were less than those in the short-term lease samples (4994.86Yuan (722.26US dollars) per hectare). The employees per hectare in the long-term lease samples ( 88.60 per hectare) were less than those in the short-term lease samples (111.41 per hectare).

Table4. Comparison of variables in different land ownerships and land lease terms

\begin{tabular}{|c|c|c|c|c|c|}
\hline \multicolumn{2}{|c|}{ Land ownerships and land lease terms } & $\begin{array}{c}\text { DJoutput } \\
\text { (Thousan } \\
\text { d US } \\
\text { dollars/ } \\
\text { hectare) }\end{array}$ & $\begin{array}{c}\text { Land } \\
\text { Area } \\
\text { (hectare) }\end{array}$ & $\begin{array}{c}\text { DJinvest } \\
\text { (Thousan } \\
\text { d US } \\
\text { dollars/ } \\
\text { hectare) }\end{array}$ & $\begin{array}{c}\text { DJemploy } \\
\text { ee } \\
\text { (number/ } \\
\text { hectare) }\end{array}$ \\
\hline \multirow{2}{*}{ Ownership } & $\begin{array}{l}\text { State-owned } \\
\text { land }\end{array}$ & 831.03 & 2.18 & 492.13 & 102.00 \\
\hline & Collective land & 669.19 & 0.58 & 340.53 & 102.88 \\
\hline \multirow{2}{*}{ Transaction } & Long term lease & 629.28 & 1.17 & 424.50 & 88.60 \\
\hline & Short term lease & 722.26 & 0.55 & 321.16 & 111.41 \\
\hline \multicolumn{2}{|l|}{ Total } & 688.23 & 0.79 & 360.33 & 102.77 \\
\hline
\end{tabular}

From Table 5, it can be seen that there is no marked difference between the two models, indicating that the endogeneity issue was not a serious problem. The effect of Ownership on DJoutput reached at the $10 \%$ significant level in the two models, and coefficients of the ownership variable were positive, indicating that the state-owned land use efficiency was higher than that of collective land. The Transaction negatively correlated with DJoutput in these two models. The effect of transaction variable on DJoutput reached at the $10 \%$ significant level in the model 2.The effect of transaction variable on DJoutput was insignificant in the model 1. In model 1, the effect of the LandArea on DJoutput was insignificant, the effect of the DJinvestment on DJoutput reached at the 5\%significant level, and the effect of DJemployee on DJoutput reached at the $10 \%$ significant level. The industrial enterprises' outputs per hectare from collective land were 2.16 million Yuan (0.31 million US dollar) and 2.06 million Yuan ( 0.30 million US dollar) less than those from state land in the two models, respectively. The outputs per hectare of industrial enterprises using the long term lease were 1.30 million Yuan ( 0.19 million US dollar) less than those using the short term lease in the model2.

Table5. Results of model estimation

\begin{tabular}{cccc}
\hline \multirow{2}{*}{ Model } & \multirow{2}{*}{ Independent variables } & \multicolumn{2}{c}{ Dependent variable } \\
& & Coefficient & Robust Std. Err. \\
\hline
\end{tabular}




\begin{tabular}{cccc}
\hline & Constant & $470.23^{* * *}$ & 89.17 \\
& Ownership & $312.12^{*}$ & 170.90 \\
Model 1 & Transaction & -86.44 & 70.66 \\
& LandArea & -12.55 & 41.13 \\
& DJinvestment & $0.10^{* *}$ & 0.05 \\
& DJemployee & $1.48^{*}$ & 0.82 \\
& Adjusted R & 0.15 & \\
F & 8.71 & 90.62 \\
& Constant & $722.26^{* * *}$ & 175.48 \\
& Ownership & $297.32^{*}$ & 107.52 \\
& Transaction & $-188.54^{*}$ & \\
& Adjusted R & 0.01 & \\
& F & 2.53 & \\
\hline
\end{tabular}

$*$ Significance at $10 \%$. **Significance at $5 \%$. ***Significance at $1 \%$.

\section{Discussion}

Rapid urbanization and industrialization has pushed the demand of land resource and reform of land market (Huang et al., 2016, Yang, 2016). Wuxi City is one of the pioneer cities of China's land market reform. A unique rural construction land market has been set up in Wuxi where enterprises and individuals can use both state-owned land and collective land. So our study in Wuxi can provide valuable information of the effect of China's dual land ownerships and different land lease terms on the efficiency of rural town industrial land use. Different from pervious qualitative studies (Wang and $\mathrm{Hu}, 2011$, Zhang, 2014, Zhang and Chen, 2008), this research was conducted based on two multiple linear regression models of questionnaires and interviews of 294 industrial enterprises.

The first theoretical hypothesis was confirmed by our results. We found that the use efficiency of the state-owned industrial land was higher than that of the collective industrial land (Table 5). According to our interview with village cadres in Wuxi, rural collective industrial land lacked legal transfer and mortgage right, and enterprises' right of disposing collective land was limited, so the property right of the collective industrial land is relatively insecurity. Clear property right is the key to promote long-term investment and improve the efficiency of land use (Deininger and Ali, 2008, Feder and Onchan, 1987, Ma et al., 2015). Our interview confirmed that the unclear property right of collective land provided insufficient incentives of effective utilization of land resource.

The second theory hypothesis was not supported by our results. Generally speaking, long-term leases of land contract can reduce transaction costs per year, but short-term lease may restrict the long-term investment from land user (Kumari and Nakano, 2016). The current research found the land lease terms negatively correlated with the use efficiency of rural industrial land, indicating that industrial land use efficiency was more efficient in short-term lease than in long-term lease. It is a bit unexpected. According to the interviews with the village cadres, this is mainly due to that the end of the short-term lease does not really mean to completely cancel the lease relationship. When the land lease term ends, most enterprises will renew the contract with the collective village. The 
land lease term does not affect the stability of land property right. On the contrary, the collective villages prefer to choose the short-term lease to gain more land value-added benefits. According to the interview with the village cadres, the transfer ownership of collective land nominally belongs to the village collectives; however, as long as get permission of the village collectives, the factory buildings can be transferred. When the factory buildings are transferred, the property rights of the land where the factory buildings locate can be also transferred. Most industrial enterprises in Wuxi are small and medium-sized enterprises and their survival cycle is generally short, and therefore they usually lack the plans to pursuit long-term benefits. Short-term lease land did not make low land use efficiency in Wuxi.

Despite higher use efficiency of state-owned land our interview found that most of the small and medium-sized industrial enterprises in the three towns preferred to choose the collective land and only a small number of them tended to choose the state-owned land. In fact, the market supply of state-owned industrial land is larger than that of the collective industrial land. It is illegal for township and village enterprises to use rural collective land, but almost all entrepreneurs have good guanxi (relations) with village cadres. On the other hand, the local government acquiesce such illegal land use for the sake of GDP increase. Using collective land, enterprises can be exempted from tedious formalities of examination and land expropriation (Lin, 2010). It also is quicker and more convenient, but with less annual rent. Only a few enterprises in the three towns we surveyed used the state-owned land. Most of these enterprises are large and comprehensive ones, with large investment from local government. Such enterprises provide industrial products and invest real estate. They rely heavily on capital and land mortgage and therefore they concern very much about the land legality and mortgage. They usually tend to choose the state-owned land.

This study was conducted in Wuxi City and the results can be applied in other areas in East China. Particularly, Yangtze River Delta is one of China's most developed areas (Li et al., 2017) where land use and cover has been change remarkably (Lai et al., 2016, Zhang et al., 2015) . With rapid industrialization, soil pollution has also emerged in the last decades (Yang et al., 2014) . Our finding in Wuxi has application in other areas in Yangtze River Delta, for example Zhejiang and Shanghai. The legality of land resource has a significant effect on efficiency of land use of the industrial enterprises. Many entrepreneurs said they would buy the state-owned land, but there was no state-owned land at rural town in early period. The collective land was also relatively cheaper. An integrated urban-rural land system and similar price of the state-owned land and the collective land may reduce the inequality of land use in these two kinds of land. According to our research, the enterprises using short-term lease have higher use efficiency of industrial land than those using long-term lease. Therefore, we propose that as long as it meets the demand of land resource from enterprises, the government may adopt tailored lease terms of industrial land to increase the utilization efficiency, rather than always 50 years.

Similar to most studies, there are some areas to be improved in the future studies. The study applied only DJoutput index to reflect the industrial land use efficiency. More indicators can be used in the future research to understand the land use efficiency more comprehensively. According to the theory of Cobb-Douglas production (CD) function (Fan et al., 2000, Koios, 2001, Murthy, 2004), it is acceptable to take double log of variables in the current study. However, considering our research is an exploring study to research the effects of dual land ownership and different land lease terms on industrial land use efficiency, two exploratory models were built and they were not 
perfect CD production functions. 16 questions were included in the questionnaire survey, more questions about enterprise characteristics in the future study will increase our understanding of factors influencing land use efficiency. The multiple linear regression model has been widely used in the studies (Choy et al., 2013, Fenske, 2011, Kumari and Nakano, 2016). Similar as previous studies (Brasselle et al., 2002, Kumari and Nakano, 2016), the adjust $\mathrm{R}^{2}$ is not very high in the current study. Considering more variables in the future studies may improve the models, but our models indeed provided valuable information. Wuxi City, East China, was selected and studied in the current study. However, the collective land market has also developed quickly in South China, such as Guangzhou and Shenzhen (Choy et al., 2013, Wu et al., 2016). Further studies in South China will provide more information of the effect of land ownerships and different land lease terms on land use efficiency.

\section{Conclusion}

Increasing urbanization and industrialization has intensified the challenge of limited land resource. Using questionnaires and interviews, we researched the effect of dual land ownerships and different land lease terms on land use efficiency in Wuxi City. Different land ownerships have significant effect on the use efficiency of rural industrial land. The use efficiency of state-owned land was higher than that of the collective land. The questionnaires and interviews confirmed the importance of legality of land property right. This is extreme important for the large enterprises which rely on land mortgage and capital investment.

According to our research, the land lease terms had negative correlation between the use efficiency of industrial land, indicated that the enterprises using short-term lease have higher use efficiency of industrial land than those using long-term lease. This is because that the collective villages prefer to choose the short-term lease to gain more land value-added benefits, most of small and medium-sized enterprises in Wuxi lack the plans to pursuit long-term benefits and renew the land contracts after the termination of previous contracts. The results highlight the importance of tailored lease terms of industrial land to increase the utilization efficiency of industrial land.

\section{Acknowledgement}

This research was fund by the National Natural Science Foundation of China (No. 41571162, 41671171, 41771189); National Key Technology R\&D Program of China "Research on the key techniques of market regulation in the redevelopment of rural construction land" (Grant Number 2013BAJ13B02); Jiangsu Province Postgraduate Innovative Research Project (Grant Number KYLX_0033). Special thanks were given to the reviewers and editor for their constructive comments and suggestions.

\section{Reference}

Abdulai, A., Owusu, V. and Goetz, R. (2011) 'Land tenure differences and investment in land improvement measures: Theoretical and empirical analyses', Journal of Development Economics, 96(1), pp. 66-78. 
Awasthi, M. K. (2009) 'Dynamics and resource use efficiency of agricultural land sales and rental market in India', Land Use Policy, 26(3), pp. 736-743.

Bao, H. and Peng, Y. (2016) 'Effect of land expropriation on land-lost farmers? entrepreneurial action: A case study of Zhejiang Province', Habitat International, 53, pp. 342-349.

Barry, M. and Roux, L. (2016) 'Land ownership and land registration suitability theory in state-subsidised housing in two South African towns', Habitat International, 53, pp. 48-54.

Besley, T. (1995) 'PROPERTY-RIGHTS AND INVESTMENT INCENTIVES - THEORY AND EVIDENCE FROM GHANA', Journal of Political Economy, 103(5), pp. 903-937.

Brasselle, A. S., Gaspart, F. and Platteau, J. P. (2002) 'Land tenure security and investment incentives: puzzling evidence from Burkina Faso', Journal of Development Economics, 67(2), pp. 373-418.

Chen, W., Peng, J. and Wu, Q. (2014) 'Spatial and Temporal Differences in Industrial Land Use Efficiency in China', Resources Science, 36(10), pp. 2046-2056.

Chen, Y., Chen, Z., Xu, G. and Tian, Z. (2016) 'Built-up land efficiency in urban China: Insights from the General Land Use Plan (2006-2020)', Habitat International, 51, pp. 31-38.

Chen, Z., Qu, F. and Huang, X. (2007) 'The Best Arrangement about Farmland in China's Economic Transition -an Analysis Made from the Perspective of Institutional Economics', Management World, (7), pp. 57-65,74.

Chen, Z., Wang, Q., Chen, Y. and Huang, X. (2015a) 'Is illegal farmland conversion ineffective in China? Study on the impact of illegal farmland conversion on economic growth', Habitat International, 49, pp. 294-302.

Chen, Z., Wang, Q. and Huang, X. (2015b) 'Can land market development suppress illegal land use in China?', Habitat International, 49, pp. 403-412.

Choy, L. H. T., Lai, Y. and Lok, W. (2013) 'Economic performance of industrial development on collective land in the urbanization process in China: Empirical evidence from Shenzhen', Habitat International, 40, pp. 184-193.

Coase, R. H. (1960) 'THE PROBLEM OF SOCIAL COST', Journal of Law \& Economics, 3(OCT), pp. 1-44.

Deininger, K. and Ali, D. A. (2008) 'Do overlapping land rights reduce agricultural investment? Evidence from Uganda', American Journal of Agricultural Economics, 90(4), pp. 869-882.

Deininger, K., Ali, D. A. and Alemu, T. (2011) 'Impacts of Land Certification on Tenure Security, Investment, and Land Market Participation: Evidence from Ethiopia', Land Economics, 87(2), pp. 312-334.

Deininger, K. and Jin, S. (2006) 'Tenure security and land-related investment: Evidence from Ethiopia', European Economic Review, 50(5), pp. 1245-1277.

Ding, C. (2007) 'Policy and praxis of land acquisition in China', Land Use Policy, 24(1), pp. 1-13.

Du, J., Thill, J.-C. and Peiser, R. B. (2016) 'Land pricing and its impact on land use efficiency in post-landreform China: A case study of Beijing', Cities, 50, pp. 68-74.

Fan, S., Wailes, E. J. and Young, K. B. (2000) 'Policy Reforms and Technological Change in Egyptian Rice Production: a Frontier Production Function Approach', Journal of African Economies, 6(3), pp. 391-411.

Feder, G. and Onchan, T. (1987) 'Land Ownership Security and Farm Investment in Thailand', American Journal of Agricultural Economics, 69(2), pp. 311-320.

Fenske, J. (2011) 'Land tenure and investment incentives: Evidence from West Africa', Journal of Development Economics, 95(2), pp. 137-156.

Field, E. (2007) 'Entitled to work: Urban property rights and labor supply in Peru', Quarterly Journal of Economics, 122(4), pp. 1561-1602. 
Galiani, S. and Schargrodsky, E. (2010) 'Property rights for the poor: Effects of land titling', Journal of Public Economics, 94(9-10), pp. 700-729.

Gao, B., Liu, W. and Dunford, M. (2014) 'State land policy, land markets and geographies of manufacturing: The case of Beijing, China', Land Use Policy, 36, pp. 1-12.

Gavian, S. and Ehui, S. (1999) 'Measuring the production efficiency of alternative land tenure contracts in a mixed crop-livestock system in Ethiopia', Agricultural Economics, 20(1), pp. 37-49.

Gavian, S. and Fafchamps, M. (1996) 'Land tenure and allocative efficiency in Niger', American Journal of Agricultural Economics, 78(2), pp. 460-471.

Hao, P., Sliuzas, R. and Geertman, S. (2011) 'The development and redevelopment of urban villages in Shenzhen', Habitat International, 35(2), pp. 214-224.

Huang, X. J., Li, Y. and Hay, I. (2016) 'Polycentric city-regions in the state-scalar politics of land development: The case of China', Land Use Policy, 59, pp. 168-175.

Jin, S. and Deininger, K. (2009) 'Land rental markets in the process of rural structural transformation: Productivity and equity impacts from China', Journal of Comparative Economics, 37(4), pp. 629646.

Koios, E. R. (2001) Cobb-douglas production function. Springer US.

Koirala, K. H., Mishra, A. and Mohanty, S. (2016) 'Impact of land ownership on productivity and efficiency of rice farmers: The case of the Philippines', Land Use Policy, 50, pp. 371-378.

Koroso, N. H., van der Molen, P., Tuladhar, A. M. and Zevenbergen, J. A. (2013) 'Does the Chinese market for urban land use rights meet good governance principles?', Land Use Policy, 30(1), pp. 417426.

Kuang, W., Liu, J., Dong, J., Chi, W. and Zhang, C. (2016) 'The rapid and massive urban and industrial land expansions in China between 1990 and 2010: A CLUD-based analysis of their trajectories, patterns, and drivers', Landscape and Urban Planning, 145, pp. 21-33.

Kumari, R. and Nakano, Y. (2016) 'Does land lease tenure insecurity cause decreased productivity and investment in the sugar industry? Evidence from Fiji', Australian Journal of Agricultural and Resource Economics, 60(3), pp. 406-421.

Lai, L., Huang, X., Yang, H., Chuai, X., Zhang, M., Zhong, T., Chen, Z., Chen, Y., Wang, X. and Thompson, J. R. (2016) 'Carbon emissions from land-use change and management in China between 1990 and 2010', Science Advances, 2(11), pp. e1601063.

$\mathrm{Li}$, J., Huang, X., Yang, H., Chuai, X. and Wu, C. (2017) 'Convergence of carbon intensity in the Yangtze River Delta, China', Habitat International, 60, pp. 58-68.

Lin, G. C. S. (2010) 'Understanding Land Development Problems in Globalizing China', Eurasian Geography and Economics, 51(1), pp. 80-103.

Liu, Q., Chen, L., Yang, J., He, C. and Shen, F. (2010) 'Econometric Analysis on Driving Forces of Cultivated Land Quantity Change in Changsha-Zhuzhou-Xiangtan Urban Agglomerations', Resources Science, 32(9), pp. 1734-1740.

Liu, R., Wong, T.-C. and Liu, S. (2012) 'Peasants' counterplots against the state monopoly of the rural urbanization process: urban villages and 'small property housing' in Beijing, China', Environment and Planning A, 44(5), pp. 1219-1240.

Liu, Y., Yang, R., Long, H., Gao, J. and Wang, J. (2014) 'Implications of land-use change in rural China: A case study of Yucheng, Shandong province', Land Use Policy, 40, pp. 111-118.

Long, H., Liu, Y., Wu, X. and Dong, G. (2009) 'Spatio-temporal dynamic patterns of farmland and rural settlements in Su-Xi-Chang region: Implications for building a new countryside in coastal China', 
Land Use Policy, 26(2), pp. 322-333.

Ma, X., Heerink, N., Feng, S. and Shi, X. (2015) 'Farmland tenure in China: Comparing legal, actual and perceived security', Land Use Policy, 42, pp. 293-306.

Manjunatha, A. V., Anik, A. R., Speelman, S. and Nuppenau, E. A. (2013) 'Impact of land fragmentation, farm size, land ownership and crop diversity on profit and efficiency of irrigated farms in India', Land Use Policy, 31, pp. 397-405.

Meng, Y., Zhang, F.-R., An, P.-L., Dong, M.-L., Wang, Z.-Y. and Zhao, T. (2008) 'Industrial land-use efficiency and planning in Shunyi, Beijing', Landscape and Urban Planning, 85(1), pp. 40-48.

Murthy, K. V. B. (2004) 'Arguing a Case for Cobb-Douglas Production Function', Econometrics, 20-21, pp. 52-58.

Pender, J. and Fafchamps, M. (2006) 'Land lease markets and agricultural efficiency in Ethiopia', Journal of African Economies, 15(2), pp. 251-284.

Po, L. (2008) 'Redefining rural collectives in China: Land conversion and the emergence of rural shareholding co-operatives', Urban Studies, 45(8), pp. 1603-1623.

Putterman, L. (1995) 'The role of ownership and property rights in China's economic transition', China Quarterly, (144), pp. 1047-1064.

Rahman, S. (2010) 'Determinants of agricultural land rental market transactions in Bangladesh', Land Use Policy, 27(3), pp. 957-964.

Rahman, S. and Rahman, M. (2009) 'Impact of land fragmentation and resource ownership on productivity and efficiency: The case of rice producers in Bangladesh', Land Use Policy, 26(1), pp. 95-103.

Shiraishi, M. and Yano, G. O. (2010) 'EFFICIENCY OF CHINESE TOWNSHIP AND VILLAGE ENTERPRISES IN THE 1990s BASED ON MICRO DATA FOR WUXI CITY, 1991-97', Developing Economies, 42(3), pp. 421-452.

Statistics, W. c. b. o. (2015) Wuxi statistical yearbook 2015. Beijing: China Statistics Press, p. 421.

Tang, B.-s. and Ho, W. K. O. (2015) 'Land-use planning and market adjustment under de-industrialization: Restructuring of industrial space in Hong Kong', Land Use Policy, 43, pp. 28-36.

Tao, R., Su, F., Liu, M. and Cao, G. (2010) 'Land Leasing and Local Public Finance in China's Regional Development: Evidence from Prefecture-level Cities', Urban Studies, 47(10), pp. 2217-2236.

Tian, L. (2008) 'The Chengzhongcun land market in China: Boon or bane? - A perspective on property rights', International Journal of Urban and Regional Research, 32(2), pp. 282-304.

Tian, L. and Zhu, J. (2013) 'Clarification of collective land rights and its impact on non-agricultural land use in the Pearl River Delta of China: A case of Shunde', Cities, 35(4), pp. 190-199.

Trischler, J., Sandberg, D. and Thornqvist, T. (2014) 'Estimating the Annual Above-Ground Biomass Production of Various Species on Sites in Sweden on the Basis of Individual Climate and Productivity Values', Forests, 5(10), pp. 2521-2541.

Tu, F., Yu, X. and Ruan, J. (2014) 'Industrial land use efficiency under government intervention: Evidence from Hangzhou, China', Habitat International, 43, pp. 1-10.

Wang, B. X., Yueming and Hu, J. (2011) 'The Plight and Countermeasures of the Transfer of Rural Collective Construction Land- Analysis on the Institutional Economics', Chinese Agricultural Science Bulletin, 27(20), pp. 186-188.

Wang, H., Zhang, X., Wang, H. and Skitmore, M. (2017) 'The right-of-use transfer mechanism of collective construction land in new urban districts in China: The case of Zhoushan City', Habitat International, 61, pp. 55-63. 
Wang, Q., Zhang, X., Wu, Y. and Skitmore, M. (2015) 'Collective land system in China: Congenital flaw or acquired irrational weakness?', Habitat International, 50, pp. 226-233.

Wu, C., Wei, Y. D., Huang, X. and Chen, B. (2017) 'Economic transition, spatial development and urban land use efficiency in the Yangtze River Delta, China', Habitat International, 63, pp. 67-78.

$\mathrm{Wu}, \mathrm{Y}$., Li, S. and Yu, S. (2016) 'Monitoring urban expansion and its effects on land use and land cover changes in Guangzhou city, China', Environmental Monitoring and Assessment, 188(1).

Wu, Y. Z., Zhang, X. L., Skitmore, M., Song, Y. and Hui, E. C. M. (2014) 'Industrial land price and its impact on urban growth: A Chinese case study', Land Use Policy, 36, pp. 199-209.

Xie, H. and Wang, W. (2015) 'Spatiotemporal differences and convergence of urban industrial land use efficiency for China's major economic zones', Journal of Geographical Sciences, 25(10), pp. 1183-1198.

Xiong, Q. and Guo, G. (2013) 'Productive Efficiency of Regional Urban Industrial Land in China', Resources Science, 35(5), pp. 910-917.

Xu, Y., Tang, B.-s. and Chan, E. H. W. (2011) 'State-led land requisition and transformation of rural villages in transitional China', Habitat International, 35(1), pp. 57-65.

Yang, H. (2016) 'China's soil plan needs strong support', Nature, 536(7617), pp. 375-375.

Yang, H., Huang, X., Thompson, J. R. and Flower, R. J. (2014) 'Soil pollution: Urban brownfields', Science, 344(6185), pp. 691-692.

Yano, G. and Shiraishi, M. (2004) 'Efficiency of Chinese Township and Village Enterprises and Property Rights in the 1990s: Case Study of Wuxi', Comparative Economic Studies, 46(2), pp. 311-340.

Ye, L., Huang, X., Xie, Z. and Zhao, X. (2015) 'Current Situation and Characteristics of the IndustrialLand of Villages and Towns under the Urban- rural Integration in Land Market: A case study of Hudai Town, Qianqiao Town, Xibei Town in Wuxi City', Land Economy Research, (01), pp. 37-58.

Zhang, J. (2005) 'State Power , Elite Relations and the Politics of Privatization in Chinese Rural Industry', Sociological Research, (5), pp. 92-124.

Zhang, M. and Chen, L. (2008) 'Resource Alloction Effect and Policy Meanings of Transfer of Rural Collective Land for Construction', China land science, 22(11), pp. 72-75.

Zhang, M., Huang, X., Chuai, X., Yang, H., Lai, L. and Tan, J. (2015) 'Impact of land use type conversion on carbon storage in terrestrial ecosystems of China: A spatial-temporal perspective', Scientific Reports, 5.

Zhang, S. (2014) 'Research on Collective construction land circulation system', The Proceedings of Hunan normal university, (3), pp. 114-119.

Zhang, X. (2013) 'Seeking Just Compensation for Collective-Owned Land Expropriation in China', Social Science Electronic Publishing.

Zhong, T., Huang, X., Ye, L. and Scott, S. (2014) 'The Impacts on Illegal Farmland Conversion of Adopting Remote Sensing Technology for Land Inspection in China', Sustainability, 6(7), pp. 4426-4451. 